\title{
How Syria Crisis Affects the Potable Water System Efficiency in Non-State Armed Group Controlled Areas
}

\section{Suriye Krizi, Devlet Dışı Grupların Kontrolü Altındaki Bölgelerde İçme Suyu Verimliliğini Nasıl Etkiliyor}

\author{
Abdullah SAGHIR \\ Syrian Engineers for Construction and Development Organization (SECD) Gaziantep- Turkey \\ a.saghir@secdo.org
}

Received Date: 29.01.2018, Accepted Date: 25.05.2018

\begin{abstract}
The purpose of this study/technical assessment was understanding the effects of the crisis of Syria on water sector in the area out of the control of Syria regime (Non-State Armed Group controlled areas), and defined the worst communities, located in Daret Azza sub district/Aleppo governorate, which need urgent technical and financial assistance in the fields of water and sewage sectors. The study showed that $100 \%$ of wastewater was not be treated because of lack of wastewater treatment plants. There was no water distribution network and also $91 \%$ of the people in the community has not accessed to the public water network. The water-supply infrastructure was not efficient. Therefore, all water-supply infrastructure in Daret Azza subdistrict was needed to rehabilitate and maintenance. The people of Daret Azza subdistrict spent about 8-13\% of their income for purchasing unsafe water while the people living in the Regime-controlled areas spent about $0.5-1 \%$ of their income for purchasing safe water. For this reason, the people of Non-State Armed Group controlled areas needed urgent and sustainable technical and financial supports, especially for obtaining potable water.
\end{abstract}

Keywords: Water supply, Syria crisis, water system, Daret Azza

Öz

$\mathrm{Bu}$ çalışmanın ya da teknik değerlendirmenin amacı, Suriye'de yaşanan krizin Suriye rejiminin kontrolünün dışında kalan alanlardaki (devlet dışı silahlı grupların kontrolündeki alanlar) su sektörü üstündeki etkilerini anlamaktır. Ayrıca, su ve kanalizayon sektörlerinde acil teknik ve mali yardıma ihtiyacı olan Halep Valiliğinin yönetimdeki Daret Azza nahiyesindeki en kötü durumda bulunan toplulukları belirlemek amaclanmaktadır. Bu çalışma ile ülkede arıtma tesisleri bulunmadığı için atıksuların tamamının arıtılmadığını gösterilmiştir. Aynı zamanda su dağıtım şebekesi de bulunmamakta ve nahiye nüfusunun \%91'i kamu su şebekelerine erişememektedir. Su temin altyapısı yeterli değildir. Bundan dolayı, tüm su temin altyapısının rehabilite edilmesi ve bakımlarının yapılmasına ihtiyaç vardır. Daret Azza nahiyesindeki insanlar gelirlerinin \%8-13 kadar kısmını güvenilmez su için harcarken rejimin kontrolü altındaki bölgelerde yaşayanlar gelirlerinin \%0.5-1'ini harcamaktadırlar. Bu nedenle, devlet dışı silahlı grupların kontrolündeki alanlarda yaşayan insanlar, özellikle içme suyuna erişimde acil, sürdürülebilir teknik ve mali desteğe ihtiyaç duymaktadırlar.

Anahtar kelimeler: Su arzl, Suriye krizi, su sistemi, Daret Azza 


\section{Introduction}

In recent years, water resources are under an increasing stress due to impacts of climate change, population increase and economic development (Selek et al.,2018).

Before the conflict of Syria at 2011, nearly $85 \%$ of the population in Syria accessed well-developed, state-owned, and centrally-managed water systems. Most of the water systems in rural Syria is defined as intermittent water supply on the contrary millions of people throughout worldwide have access to water consistently (Van den Berg et al, 2011). In the rural areas of Syria, piped water supply services are considered as intermittent water supply (IWS), that means the water is available only limited hours per a day (Ilaya-Ayza et al., 2017).

On the other hand, Syrian major cities only have sewage systems including treatment plants while other parts of the country relied on simpler technologies. The public institutions manage water systems in towns, cities and villages. About $85 \%$ of the population of towns and cities in Syria obtained their water needs form public water systems, on the other hand the others (about 20\%) obtained potable water from other water resources such as private water well, water tracking etc. An average Syrian consumes drinking water about 100-200 liter/a day. The population in Daret Azza subdistrict obtains water from deep water wells which supply with Syrian standard on drinking water (SAOSM, 2007).

The Syrian conflict has enveloped the entire country and has led to socially, economically and civilly mass-scale destruction at all levels of society. The conflict has led to one of the worst humanitarian crises of modern history, leaving a particular impact on the most vulnerable populations of women and children. The water systems and wells have deteriorated drastically due to the conflict. Materials such as diesel for generators, chlorine etc. for operating water systems healthy and efficiently are extremely limited due to high prices and non-availability. Furthermore, during the 2014 and 2015 season, Syria has experienced one of the worst droughts affecting negatively all kinds of water systems of the last several years. Humanitarian intervention has thus far largely focused on emergency response including water trucking and the provision of bottled water.

It is estimated that $80 \%$ of water infrastructure in Syria is in need of rehabilitation and maintenance (UN-OCHA, 2018; HNO, 2017). As a consequence of the combined effect of infrastructure breakdown and scarce of water, an increasing proportion of the population nowadays depends on trucked water, provided by both 
the public and private sectors, which are not regulated or resorting to unprotected water sources, and have witnessed increases in prices.

Additionally, as a result of the lack of electricity in these cities, water stations do not work, it is need to have diesel/fuel oil to operate them. The number of displaced persons and communities in these cities and towns has increased day after day as a result of the lack of potable water. On the other hand, the poverty level is also rising and every family needs to have about $10-20 \$$ monthly for purchasing unsafe water. This amount in general is not available to Syrian poor people, as 80 percent of its population live at or below the national poverty line in Syria. Moreover, the lack of electricity has had negative impacts across sectors, including health, and water, sanitation and hygiene (WASH). Indeed, 13 million of Syrian people have not chance to access permanently healthy water. The population, live in areas that are out of control of the regime, often depends on water tanks and other sources, supplied by private companies. This situation poses enormous financial burden on Syrian households (UN-OCHA, 2018; HNO, 2017).

Similar to several other systems in MENA (Middle East and North Africa) region, the water systems in Syria are characterized as being urban; modern and extensive. Water and sewage networks require increased support to continue providing a minimum level of services (UN-OCHA, 2017, HNO, 2016). The assessment objectives may be summarized as given below.

- Define the worst communities in water and sewage sector which need urgent technical and financial assistance.

- Drawing true picture about water infrastructure in the areas, out of the Syrian regime control.

- Understanding the negative effects of the war on the water sector in the areas out of Syrian regime control (UNICEF, 2017).

\section{Methods}

This research focused on Daret Azza subdistrict, located on Jebel Saman district in Syria, and managed by Aleppo governorate, Non-State Armed Group NSAG-controlled areas since the end of 2012 (Figure 1-2). Its population is about 109.612 people (47.637 internally displaced persons (IDPs), 61.975 local people) as showed in the table 1 (IOM, NPM, 2017). 
Table 1

The Total Number of Population of Daret Azza Subdistrict Communities

\begin{tabular}{cccccc}
\hline Country & Governorate & District & Sub-district & Community & $\begin{array}{c}\text { Number of } \\
\text { population }\end{array}$ \\
\hline Syria & Aleppo & Jebel Saman & Daret Azza & Hur & 3474 \\
Syria & Aleppo & Jebel Saman & Daret Azza & Tqad & 8067 \\
Syria & Aleppo & Jebel Saman & Daret Azza & Arhab & 3359 \\
Syria & Aleppo & Jebel Saman & Daret Azza & Majbineh & 2674 \\
Syria & Aleppo & Jebel Saman & Daret Azza & Bsartun & 5500 \\
Syria & Aleppo & Jebel Saman & Daret Azza & Anjara & 12.754 \\
Syria & Aleppo & Jebel Saman & Daret Azza & Zarzita & 4030 \\
Syria & Aleppo & Jebel Saman & Daret Azza & Hoteh & 8384 \\
Syria & Aleppo & Jebel Saman & Daret Azza & Bshantara & 1265 \\
Syria & Aleppo & Jebel Saman & Daret Azza & Bishqatine & 1174 \\
Syria & Aleppo & Jebel Saman & Daret Azza & Kafrantin & 225 \\
Syria & Aleppo & Jebel Saman & Daret Azza & Qabtan & 4811 \\
Syria & Aleppo & Jebel Saman & Daret Azza & Daret Azza & 43.320 \\
Syria & Aleppo & Jebel Saman & Daret Azza & Deir Saman & 7000 \\
\hline
\end{tabular}
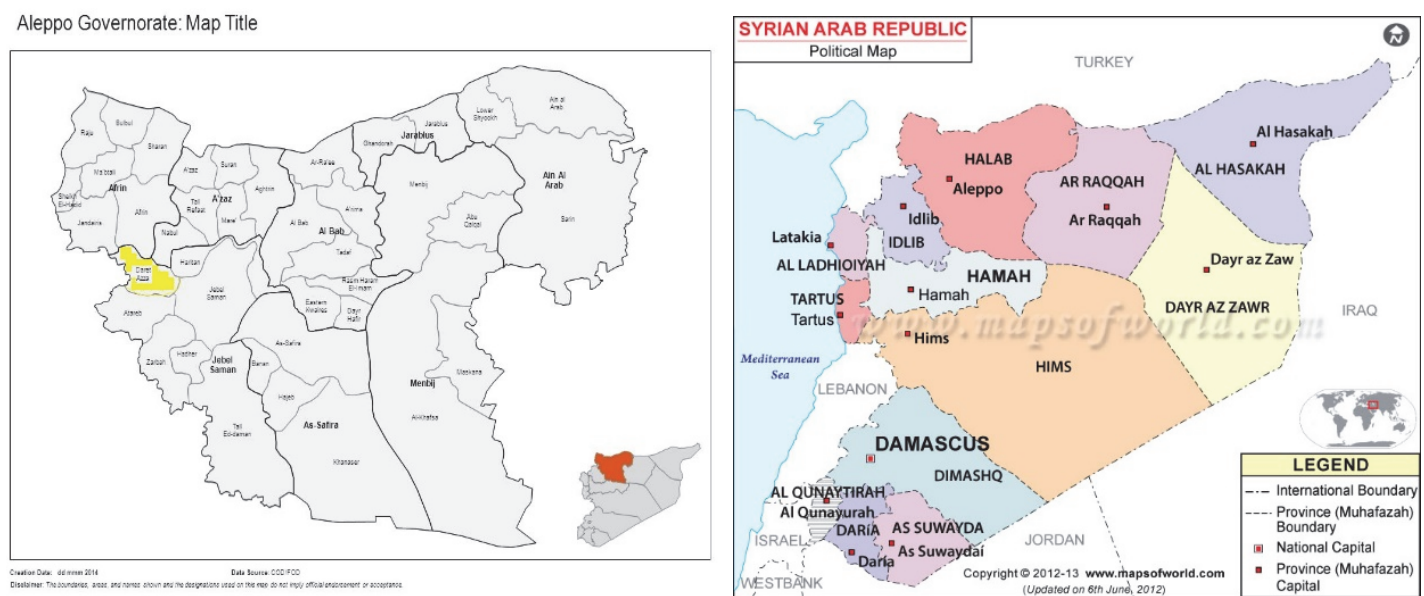

Figure 1-2. Syria map, Aleppo governorate and Daret Azza subdistrict location.

The water system in Daret Azza subdistrict consists of the following parts:

- Mechanical devices: Horizontal and vertical pumps, generators, pips, valves, chlorine dosing pumps.

- Civil infrastructure: ground water tank, high water tank, distribution rooms, control rooms.

- Electrical infrastructure: Cables, transformer and control panels. 
SECD (Syrian Engineers for Construction and Development) organization team collaboration with United Nations Children's Emergency Fund (UNICEF) and Water, Sanitation and Hygiene (WASH) cluster/Turkey hub conducted a project for technical assessment of water stations in Daret Azza subdistrict, and also SECD team made a needs assessment for rehabilitation of its sewer system. The assessment of water stations at Daret Azza subdistrict was conducted by five technical engineers of SECD in the field.

SECD used the following simple equation which usually used by UNICEF (UNICIEF, 2017) for assessment of water stations. This method is familiar in Syria and most of water engineers use this equations for calculate the composite indicator.

$$
\mathrm{I}_{\mathrm{C}}=\mathrm{W}_{1} \times \mathrm{I}_{1}+\mathrm{W}_{2} \times 1_{2}+\mathrm{W}_{3} \times \mathrm{I}_{3}+\ldots+\mathrm{W}_{\mathrm{N}} \times \mathrm{I}_{\mathrm{N}}
$$

Where $\mathrm{W}_{\mathrm{N}}$ is a weight for the $\mathrm{N}^{\text {th }}$ component indicator $\left(\mathrm{I}_{\mathrm{N}}\right), \mathrm{I}_{\mathrm{C}}$ is the composite indicator and $\mathrm{W}_{1}+\mathrm{W}_{2}+\mathrm{W}_{3}+\ldots+\mathrm{W}_{\mathrm{N}}=100 \%$ (UNICIEF, 2017).

For Daret Azza subdistrict, the water-supply infrastructure efficiency (WSIE) can be calculated by the equation given below.

WSIE $=(55 \%)$ mechanical devices efficiency $+(30 \%)$ civil infrastructure + $(15 \%)$ electrical infrastructure

The value of weight was calculated according to the cost and the importance of the indicator. In general, for water station of Daret Azza the average cost of rehabilitation of mechanical devices was about $55 \%$, and the cost of rehabilitation civil infrastructure was about $30 \%$, and the cost of electrical infrastructure related to water stations was about $15 \%$. Each indicator consists of many sub indictors:

- Mechanical devices consist of many sub indictors: Is there a stand-by submersible pump(s) ready to use? The answer should be: yes or no.

- Is there a stand-by horizontal pump(s) ready to use? The answer should be yes or no.

- Is there a stand-by chlorine pump(s) ready to use? The answer should be yes or no.

- Does the submersible pump(s) functions? The answer should be yes or no.

○ Does the Horizontal/vertical pump(s) functions? The answer should be yes or no. 
- Does the generators functions? The answer should be yes or no.

- Do the pipes and valve(s) functions? The answer should be yes or no.

- Does the Horizontal/vertical pump(s) functions? The answer should be yes or no.

○ Is there a submersible pump(s) ready to use? The answer should be yes or no.

O Is there a horizontal pump(s) ready to use? The answer should be yes or no.

- Is there a chlorine pump(s) ready to use? The answer should be yes or no.

- Is there a generator pump(s) ready to use? The answer should be yes or no.

- Civil infrastructure consists of many sub indictors:

$\circ$ Does the ground water tank (s) functions? The answer should be yes or no.

- Does the high-water tank functions? The answer should be yes or no.

- Does the distribution room(s) functions? The answer should be yes or no.

- Does the control room(s) functions? The answer should be yes or no.

- Electrical infrastructure consists of many sub indictors:

$\circ \quad$ Is there a stand-by cables (s) ready to use? The answer should be yes or no.

- Is there a stand-by transformer (s) ready to use? The answer should be yes or no.

- Is there a stand-by control panels to use? The answer should be yes or no.

- Does the cables (s) functions? The answer should be yes or no.

- Does the transformer (s) functions? The answer should be yes or no.

- Does the control panels s function? The answer should be yes or no.

- Is there a sufficient cables (s) ready to use? The answer should be yes or no.

- Is there a sufficient transformer (s) ready to use? The answer should be yes or no.

- Is there a sufficient control panel? The answer should be yes or no. 
- Water System Efficiency (WSE) = (45\%) mechanical devices efficiency $+(30 \%)$ civil infrastructure $+(15 \%)$ electrical infrastructure + $(10 \%)$ Availability of technical people at a water station

- Maximum Production Capacity of Water Stations (MPCoWS) $\left(\mathrm{m}^{3} /\right.$ day): The amount of water produced by all water wells if the water pump work about 16 hours per a day (it is assumed that all water stations are function).

- Maximum Amount of Water for Per Person (MAoWP) (1/person, day) $=$ Maximum production capacity $\times 1000 \times 0.8 /$ number of population.

- The Actual Average Water Consumption for Per Person (AAWCP) $(1 /$ person, day $)=$ the amount of water consumption per person per day. SECDO team consulted the families, selected randomly lived in the target location and reported the values about water uses. Before the crisis in Syria, each people consumed about 80-150 liter /day of drinkable water. However, after the Syrian crisis, the water consumption has been getting lower and lower because of the scarcity of water and the extreme high water prices.

- Actual Production Capacity of Water Station (APCoWS) $\left(\mathrm{m}^{3} /\right.$ day): According to the lack of public electricity and diesel for the generator in water station. In the water stations, water does not produced stably so the value of APCoWS is equal to 0 when there is not public electricity and diesel for the generator in water station, and sometime its value equal to MPCoWS.

\section{Results}

SECDO team during October and November of 2017 conducted the work for the understanding of sewerage and water system infrastructures that were located in Daret Azza district. The results of the assessment are shown in the tables 2, 3 and 4. 
Table 2

The Technical Assessment Results for Sewer Network of Daret Azza Subdistrict Communities

\begin{tabular}{|c|c|c|c|c|c|}
\hline Community & $\begin{array}{c}\text { \% of people } \\
\text { served by public } \\
\text { Sewer network }\end{array}$ & $\begin{array}{l}\text { Amount of } \\
\text { Wastewater } \\
\left(\mathrm{m}^{3} / \text { day) }\right.\end{array}$ & $\begin{array}{l}\text { Percent } \\
\text { amount of } \\
\text { treated } \\
\text { wastewater } \\
(\%)\end{array}$ & $\begin{array}{l}\text { Existence } \\
\text { of WWTP } \\
\text { (Yes/No) }\end{array}$ & $\begin{array}{l}\text { Registered } \\
\text { cutaneous } \\
\text { leishmaniasis } \\
\text { Cases during } \\
\text { 2017 (ACU, } \\
\text { EWARN 2017) }\end{array}$ \\
\hline Hur & $77 \%$ & 133.4 & 0 & $\mathrm{NO}$ & 89 \\
\hline Tqad & 82 & 374.3 & 0 & NO & 117 \\
\hline Arhab & $72 \%$ & 137.0 & 0 & NO & \\
\hline Majbineh & $65 \%$ & 109.1 & 0 & NO & \\
\hline Bsartun & $82 \%$ & 193.6 & 0 & NO & \\
\hline Anjara & $83 \%$ & 581.6 & 0 & NO & 183 \\
\hline Zarzita & $0 \%$ & 154.8 & 0 & NO & \\
\hline Hoteh & $68 \%$ & 288.4 & 0 & NO & $6^{(1)}$ \\
\hline Bshantara & $69 \%$ & 52.6 & 0 & NO & \\
\hline Bishqatine & $72 \%$ & 49.8 & 0 & NO & \\
\hline Kafrantin & $0 \%$ & 8.8 & 0 & NO & \\
\hline Qabtan & $83 \%$ & 234.8 & 0 & NO & 205 \\
\hline Daret Azza & $89 \%$ & 2218.0 & 0 & $\mathrm{NO}$ & 371 \\
\hline Deir Saman & $73 \%$ & 274.4 & 0 & NO & \\
\hline
\end{tabular}

Note. Amount of Wastewater $\left(\mathrm{m}^{3} /\right.$ day $)=0.8 \times$ number of population $\times$ the average water consumption (1/person. day) $/ 1000, W W T P=$ wastewater treatment plant.

Note ${ }^{1}$. This value for only 11 weeks and the other value cover all 2017 


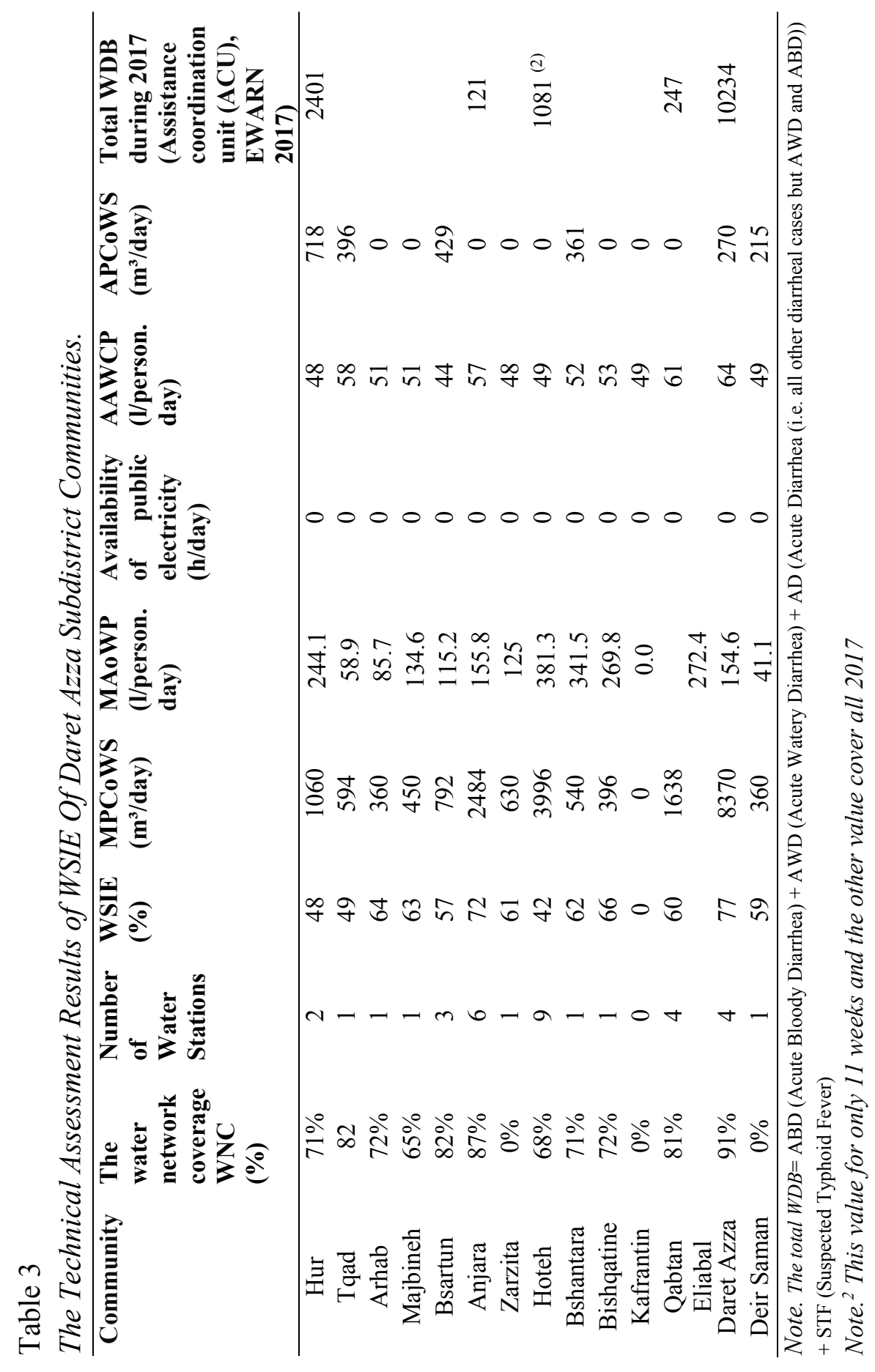




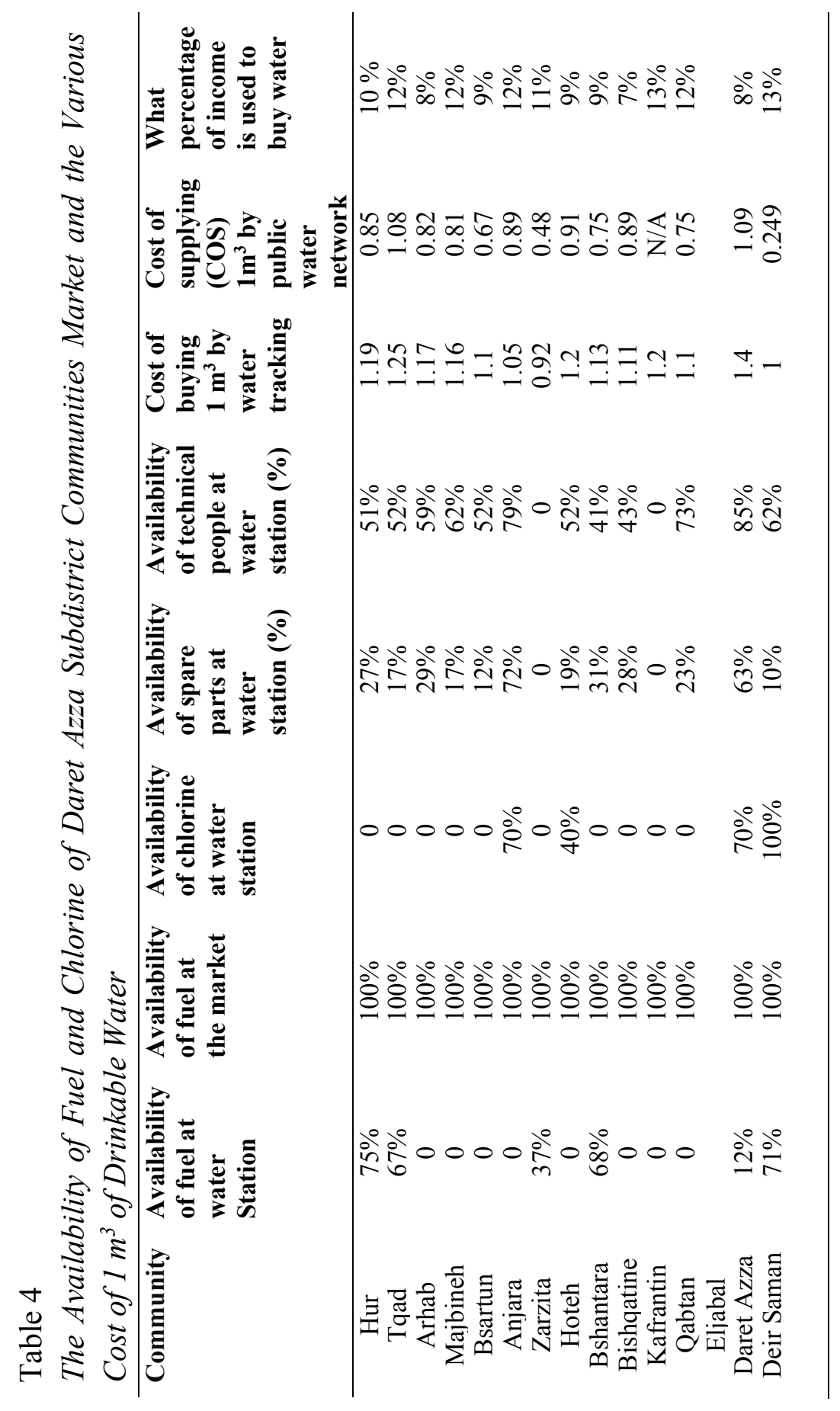


$1-100 \%$ of wastewater do not be treated because there is not a wastewater plant. Therefore, the cutaneous leishmaniasis is disseminated through country. Ground water are also polluted. According to ACU Reports, there were totally 14.536 patients with waterborne diseases and 971 patients with cutaneous leishmaniasis in Daret Azza subdistrict during 2017 . Local council and any nongovernmental organizations of NSAG-controlled areas do not have enough financial and technical resources for constructing wastewater treatment plant (ACU, EWARN 2017).

2-All sewer network is functioning, but there is a need to rehabilitate most of them. Additionally, Kafrantin and Zarzita communities do not have sewer network, so day by day, the water resources are getting polluted more and more.

3-The WNC values are about $0 \%$ (which mean there is not water network) and $91 \%$ of the houses of the communities have not access to the public water network. Zarzita, Deir Saman and Kafrantin communities till now (30.12.2017) did not have water supply network. Therefore, it is so important to construct new water systems in the locations which did not have any water supply networks or had dysfunctional networks, and also to extend to the areas that did not have this system.

4-WSIE is about $0 \%$ (which mean there is not water station because some communities in Syria do not have water station till now, and the people get obtain water from other communities) to $71 \%$. Water-supply infrastructure in Daret Azza subdistrict should be rehabilitated and maintained, but the local authorities of Daret Azza do not have enough financial resources for making necessary rehabilitation. SECD, World Vision International (WVI), and other non- government organizations (NGOs) worked in Daret Azza for solution of water issues. Similarly, they also do not have enough financial resources to fix all the problems related to water system.

5-AAWCP (1/person.day) is about 44-64 liter/day. It is similar to the value in the export of WoS-WASH Clusters which the average number of water consumption of each person in Daret Azza subdistrict is explained as 61.73 liter/day.

6-MAoWP (1/person.day) values for Daret Azza communities are various among 0 (for the communities no having water stations) and the maximum value with 381.3 liter ( $1 /$ person.day). This indicator is very important to determine their needs to establish new water stations. If MAoW value should be less than 50 liter/person, there will be a need to construct a new water station. Therefore, Deir Saman village urgently needs a new drinkable water resource. Most of water stations has not produced water because of lack of electricity and diesel for the generators replaced in water stations. In addition to, local councils and water units do not have enough 
financial resources for covering the operating costs of supplying water. On the other hand, a number of NGOs have supported certain local councils and water units such as Bsartun and Hur etc. By this way, they may provide potable water for their people, and the others such as Deir Saman, Daret Azza may conduct recovery costs, even if just drop. After all, water units and local councils in Daret Azza have needed uninterrupted support, as $85 \%$ of Syrian people has lived under the poverty line according to OCHA reports.

7-The cost of $1 \mathrm{~m}^{3}$ by water trucking in Daret Azza communities is between 0.249$1 \$$ while in the regime-controlled areas, it is about $0-0.13 \$ / \mathrm{m}^{3}$ (MoWR, Order 894, 2014). Because the fee for water supplying service is determined by government. On the other hand, this water is not healthy, as it has not be disinfected. In parallel with this, the indicator of water disease born of Daret Azza is getting higher and higher according to reports of the ${ }^{3}$ Early Warning Alert and Response Network Program (ACU, EWARN 2017).

8-COS of $1 \mathrm{~m}^{3}$ of drinking water by public water network in Daret Azza communities is between 0.92-1.4 \$. (Figure 5). Contrarily, this water is healthy depending on many factors: the depth of ground water table, the length of water networks etc. The maximum value of COS in Daret Azza and Tqad is shown as Figure 6. Because the ground water table level is too high, and the dynamic level in these communities is about $-450 \mathrm{~m}$.

\footnotetext{
${ }^{3}$ Surveillance is a systematic and continuous collection of epidemiological health data within a specific time frame, and therefore the interpretation and dissemination of such information in the field of public health. Surveillance is essential in the planning, implementation and evaluation of public health practices. The Early Warning Alert and Response Network is a simplified disease surveillance system created in the affected north of Syria after the collapse of the health system in mid-2013.
} 


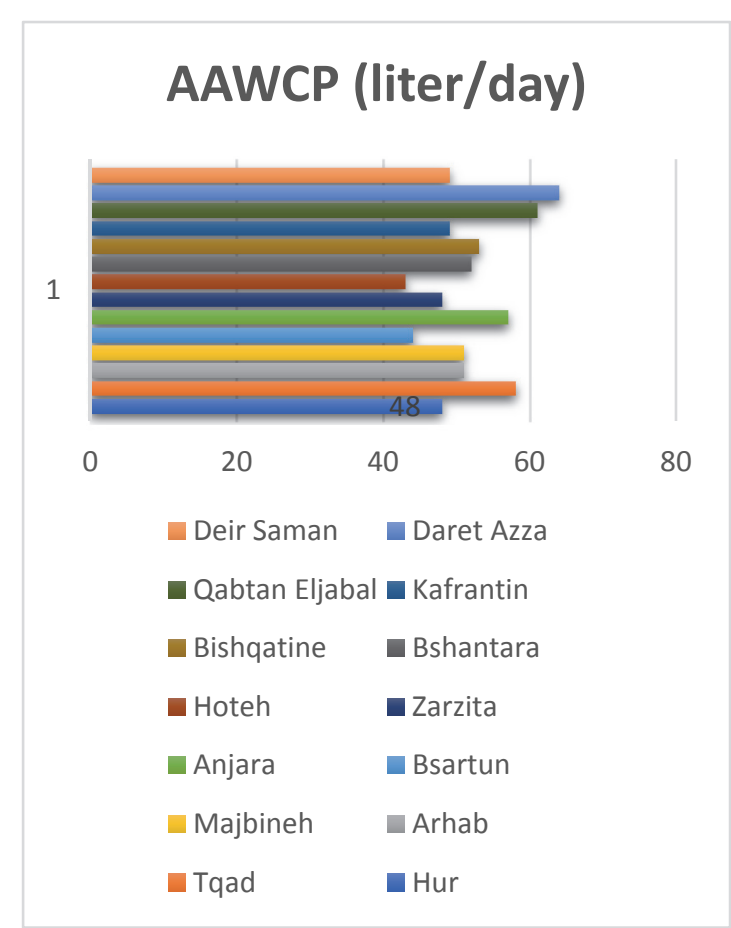

Figure 3. AAWCP (1/person.day) of Daret Azza subdistrict communities.

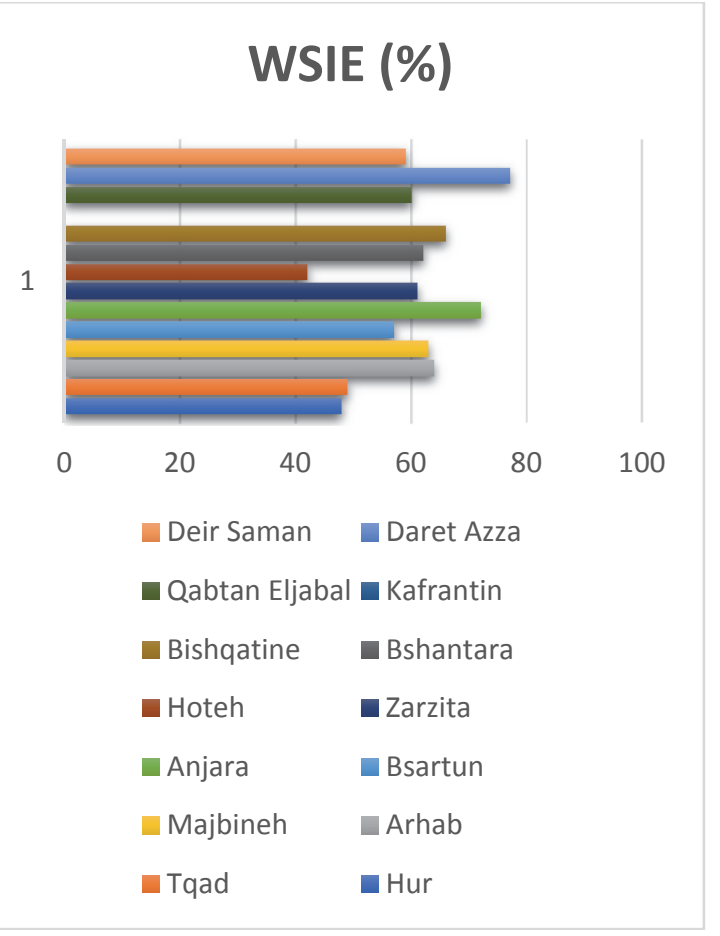

Figure 4. WSIE (\%) of Daret Azza subdistrict communities.

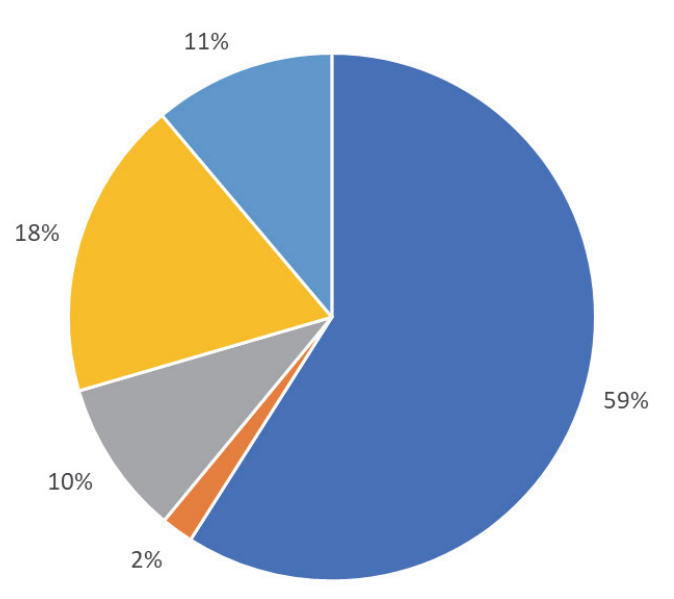

" cost of Fuel $\|$ cost of oil $\|$ cost of chlorine $\|$ cost of workers $\|$ cost of maintenance

Figure 5. The cost segregation of supplying $1 \mathrm{~m}^{3}$ of drinking water by public water network of Daret Azza communities. 


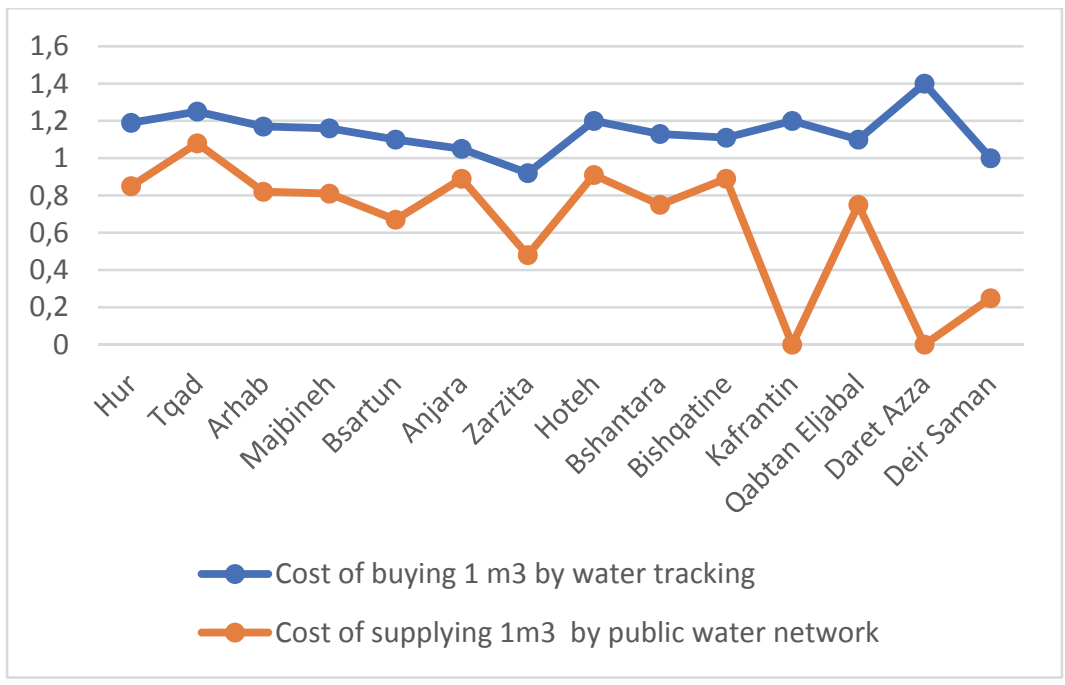

Figure 6. The cost of supplying $1 \mathrm{~m}^{3}$ of drinking water by public water network and the cost of buying $1 \mathrm{~m}^{3}$ by water tracking.

9-The people of Daret Azza communities spends about 8-13\% of their income for buying unsafe water. The amount is so high for them as shown in Figure 7 . The people living in the regime controlled areas spends about $0.5-1 \%$ of their income, as fee for water supplying services is determined as $0-0.13 \$ / \mathrm{m}^{3}$ by the government Before 2011, most of Syrian people spends about $0.3-1 \% \$ / \mathrm{m}^{3}$, so the people in NSAG and potable water sectors need uninterrupted financial and technical supports.

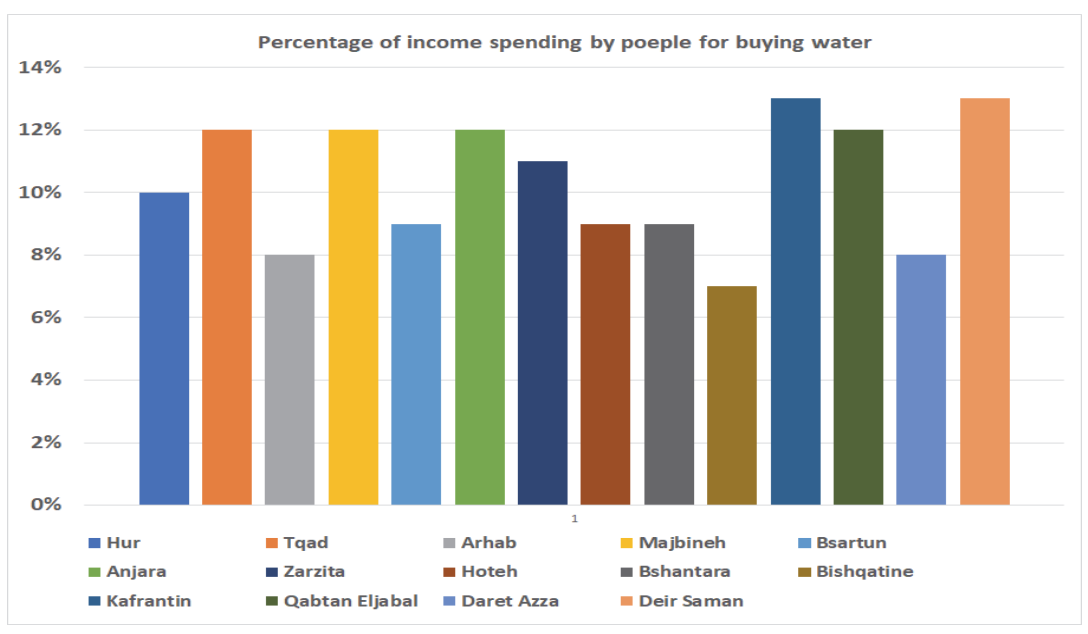

Figure 7. The percentage of income spending by people for buying water by track in Daret Azza subdistrict communities. 


\section{Conclusion}

The assessment showed that the people in NSAG-controlled areas needs urgent and sustainable technical and financial supports, especially for obtaining drinking water. The unhealthy water which is supplied by water tracking is the root cause of high WDB during 2017. 14.536 patients with WDB was registered in 2017. Additionally the untreated wastewater of Daret Azza subdistrict is one of the cause of cutaneous leishmaniasis during 2017.

\section{Acknowledgement}

This study was conducted considering the outcomes of Rapid Complementary Integrated Response on Water, Sanitation, and Hygiene (WASH) Services of new and recently internally displaced people and also hosted people in the northwest of Syria. It was started at 15.03.2018 and finished at 14.06.2018, and also funded by United Nations Office for the Coordination of Humanitarian Affairs Turkey. 


\section{References}

Assistance Coordination Unit. (2018). Early Warning alert and Response Network (EWARN)_WBD_Leish_daretazza 2017. Retrieved from https://www.acu-sy.org/en/ewarnreports/

Ilaya-Ayza, E. A., Benítez, J., Izquierdo, J., \& Pérez-García, R. (2017). Multi-criteria optimization of supply schedules in intermittent water supply systems., Journal of Computational and Applied Mathematics, 309, 695-703. Retrieved from https://doi.org/10.1016/j.cam.2016.05.009

International Organization for Migration. (2017)., Needs and Population Monitoring Programme for Syria. MDSM Shared Dataset, IOM.

Ministry of Water Resources. (2014). Order 894 about the price of water/Tariffa price. Retrieved from

http://www.dawssa.gov.sy/site/arabic/index.php?node=551\&cat=14761\&First=0\&Last=2\&Curre ntPage $=0 \&$ src $=$ search $\&$ Map $=1 \&$ Part $=0 \&$ FOrder $=4 \&$ Loc $=0 \& S D a y=\& S M o n t h=\& S Y$ ear $=\& E D a$ $\mathrm{y}=\& \mathrm{EMonth}=\& \mathrm{EY}$ ear $=\&$ Keywords $=1 \mathrm{NHHxs} 0=\&$

United Nations Office for the Coordination of Humanitarian Affairs. (2017).2018 humanitarian needs overview of Syria Arabic Republic. Retrieved from https://reliefweb.int/report/syrian-arabrepublic/2018-humanitarian-needs-overview-syrian-arab-republic-enar

United Nations Office for the Coordination of Humanitarian Affairs. (2017). 2017 Syrian Arab Republic Humanitarian Response Plan. Retrieved from https://reliefweb.int/report/syrian-arabrepublic/2017-syrian-arab-republic-humanitarian-response-plan-january-december

United Nations Office for the Coordination of Humanitarian Affairs. (2016). 2017 Humanitarian Needs Overview: Syrian Arab Republic. Retrieved from https://reliefweb.int/report/syrian-arab-republic/2017-humanitarian-needs-overview-syrian-arabrepublic-enar

United Nations International Children's Emergency Fund. (2016). Report on initial findings water infrastructure survey of Syria Arabic Republic. Turkey hub

Syrian Arab Organization for Standardization and Meteorology. (2007). Drinking water - Second review, S.N.S:45/2007,ICS:67.160.20. Retrieved from http://www.moh.gov.sy/LinkClick.aspx?fileticket=L_1cf7p19DA\%3D\&portalid=0\&language=a r-YE

Selek, B., Adıgüzel, A., İritiaş, Ö., Karaaslan, Y., Kınacı, C., Muhammetoğlu, A. \& Muhammetoğlu, H. (2018). Management of water losses in water supply and distribution networks in Turkey. Turkish Journal of Water Science \& Management, 2 (1), 58-75. 
Whole of Syria -Water Sanitation Hygene Clusters. (2017). WASH assessment Amman: Second Round.

Van den Berg, C. \& Danilenko, A. (2011). The IBNET Water Supply and Sanitation Performance Blue Book. Retrieved from http://documents.worldbank.org/curated/en/420251468325154730/The-IBNET-water-supplyand-sanitation-performance-blue-book 


\title{
Extended Turkish Abstract \\ (Genişletilmiş Türkçe Özet)
}

\section{Suriye Krizi, Devlet Dışı Grupların Kontrolü Altındaki Bölgelerde İçme Suyu Verimliliğini Nasıl Etkiliyor}

\begin{abstract}
Suriye'deki savaş modern tarihin en kötü insani krizlerinden birine yol açmıştır.Tüm ülkeyi saran savaş toplumun her seviyesinde ve özellikle en savunmasız grup olan kadınlar ve çocuklar üzerinde en büyük olumsuz etkiyi yaparak sosyal ve ekonomik alanlar ile alt yapı sistemlerinde kitlesel ölçekte yıkıma yol açmıştır. Su sistemleri ve kuyular büyük ölçüde zarar görmüştür. Su temin sistemlerini işletmek için gerekli olan jeneratör, klor vb. gibi teçhizat ve kimyasalların fiyatlarının yüksek olması ve yeterince bulunamaması nedeniyle sağlıklı ve kesintisiz su arzı son derece sinırlıdır. Ayrıca, son birkaç yılda, Suriye'de, her türlü su sistemini olumsuz etkileyen en şiddetli kuraklıklar yaşanmıştır. Ülkeye yapılan insani yardımlar acil ihtiyaçlara odaklanmış, halkın su ihtiyacı tankerler ile taşınan veya şişelenmiş sularla karşılanmıştır. Bunun nedeni ise Suriye'deki su temin altyapısının \%80'inin rehabilite ve bakıma ihtiyacı olduğunun düșünülmesidir (UN-OCHA, 2018; HNO, 2017). Ülke nüfusunun büyük çoğunluğu su temin altyapısının çökmüş olması ve su kıtlığı yaşanmasının birleşik etkisi sonucu günümüzde, kamu ve özel sektör tarafından kamyonlarla taşınan ve hijyenik olmayan suyu kullanmaktadır. Su ve kanalizasyon şebekelerinin, asgari düzeyde hizmet verebilmeleri için daha fazla teknik ve mali desteğe ihtiyaç duyulmaktadır (UN-OCHA, 2017, HNO, 2016). Suriyeli Mühendisler İnşaat ve Geliştirme Organizasyonu (SECD), UNICEF ve Su, Sanitasyon ve Hijyen (WASH) ekibi, Daret Azza alt bölgesinde su istasyonu teknik değerlendirmesi için bir proje yürütmüştür. Sözkonusu ihtiyaçları belirlemek amacıyla yürütülen bu projenin alt hedefleri aşağıda siralanmaktadır:
\end{abstract}

1. Su ve kanalizasyon açısından acil teknik ve mali desteğe ihtiyaç duyulan bölgeleri belirlemek,

2. Suriye rejimi kontrolünde olmayan bölgelerin su ve kanalizasyon şebekelerinin gerçek tablolarını ortaya çıkarmak,

3. Suriye rejimi kontrolü dışındaki bölgelerde savaşın su sektörü üzerindeki olumsuz etkilerini anlamak (UNICEF, 2017).

SECD ekibi, kanalizasyon sisteminin rehabilitasyonu için bir ihtiyaç değerlendirmesi yapmıştır. $\mathrm{Bu}$ araştırma Suriye'nin Jebel Saman ilçesinde bulunan ve Halep Valiliği tarafından yönetilen Daret Azza alt bölgesine odaklanmıştır. Halep Valiliği’nin yönetimdeki Daret Azza nahiyesindeki en kötü durumda bulunan toplulukları belirlemiştir. Daret Azza alt bölgesinde yer alan su sistemi aşağıdaki kısımlardan oluşmaktadır:

1- Mekanik cihazlar: Yatay ve dikey pompalar, jeneratörler, borular, vanalar, klor dozaj pompalar1

2- Sivil altyapı: yeraltı su deposu, yüksek su deposu, dağıtım odaları, kontrol odaları

3- Elektrik altyapısı: Kablolar, trafo ve kontrol panelleri

SECD ekibi, su istasyonlarının değerlendirilmesinde UNICEF (UNICIEF, 2017) tarafından kullanılan aşağıdaki basit denklemi kullanmıştır. Bu denklem Suriye'deki su mühendislerinin çoğu tarafından kompozit göstergeyi hesaplamak için kullanılmaktadır.

$$
\mathrm{I}_{\mathrm{C}}=\mathrm{W}_{1} \times \mathrm{I}_{1}+\mathrm{W}_{2} \times 1_{2}+\mathrm{W}_{3} \times \mathrm{I}_{3}+\ldots+\mathrm{W}_{\mathrm{N}} \times \mathrm{I}_{\mathrm{N}}
$$


(Ic) kompozit göstergesi $=\mathrm{W} 1+\mathrm{W} 2+\mathrm{W} 3+\ldots+\mathrm{WN}(\mathrm{WN})$ : Nth'nin ağırlık değeri (In): bileşen göstergesi =\% 100 (UNICEF, 2017).

Daret Azza alt bölgesi için Su tedarik altyapısı verimliliği (WSIE) şu şekilde hesaplanabilir:

$\mathrm{WSIE}=(\% 55)$ mekanik cihazlar verimliliği $+(\% 30)$ sivil altyapı $+(\%$ 15) elektrik altyapısı.

Ağırlık değeri, maliyete ve göstergenin önemine göre hesaplanmıştır. Daret Azza su istasyonu için mekanik cihazların ortalama rehabilitasyon maliyeti yaklaşık \%55, rehabilitasyon sivil altyapısının maliyeti yaklaşık \%30, su istasyonları ile ilgili elektrik altyapısının maliyeti yaklaşık \%15'dir. Her gösterge birçok alt göstergeden oluşmaktadır. Yapılan hesaplamalar ve çalışmalar neticesinde; aşağıdaki sonuçlara ulaşılmıştır.

1. Atık su tesisinin olmaması nedeniyle atık suyun \%100'ü arıtılamamaktadır. Bu nedenle, kutanöz leishmaniasis hastalığı ülke çapında yayılmaktadır. ACU raporlarına göre, 2017 yılında Daret Azza alt bölgesinde, su kaynaklı hastalıkları olan toplam 14.536 hasta ve kutanöz leishmaniasisli 971 hasta kaydedilmiştir. Ayrıca, yeraltı suları da kirlenmiştir.

2. Tüm kanalizasyon şebekesi çalışmaktadır, ancak bunların çoğunun iyileştirilmeye ihtiyacı bulunmaktadır. Fakat Kafrantin ve Zarzita topluluklarının kanalizasyon şebekesi yoktur, bu yüzden her geçen gün su kaynakları giderek daha fazla kirlenmektedir.

3. WNC değerleri yaklaşık \% 0'dır (yani su şebekesi yoktur) ve söz konusu toplulukların \% 91'i kamu su şebekesine erişememektedir. 30.12.2017 tarihi itibarı ile Zarzita, Deir Saman ve Kafrantin topluluklarının su şebekesi yoktur. Bu nedenle, herhangi bir su şebekesi bulunmayan veya çalışmayan yerlerde yeni su sistemleri inşa etmek çok önemlidir.

4. WSIE $\% 0$ civarındadır (yani su istasyonu bulunmadığı için, Suriye'deki bazı topluluklar, diğer topluluklardan su temin etmektedir). Daret Azza alt bölgesindeki su temin altyapısının \%71'nin iyileştirilmesi gerektiği halde, yerel yetkililerinin rehabilitasyon için yeterli mali kaynağı bulunmamaktadır.

5. AAWCP (1/insan*gün) yaklaşık 44-64 litre/gündür. WoS-WASH Kümelenmelerinin raporundaki değer ile örtüşmekte, Daret Azza nahiyesindeki her bir kişinin ortalama su tüketimi 61.73 litre/gün olarak açıklanmaktadır.

6. Dema Azza toplulukları için MAOWP (1/ insan*gün) değerleri en az 0 (su istasyonu bulunmayan topluluklar için) ve en çok 381,3 litre (1/insan*gün) arasındadır. Bu gösterge, yeni kurulacak su istasyonlarının ihtiyaçlarını belirlemek için çok önemlidir. MAOW değerinin 50 litreden az olması durumunda, yeni bir su istasyonu inşa edilmesine ihtiyaç olacaktır. Bu nedenle Deir Saman köyünün acilen yeni bir su istasyonuna ihtiyacı vardır.

7. Daret Azza topluluklarında $1 \mathrm{~m}^{3}$ lük su temininin maliyeti, rejim kontrolü dışındaki bölgelerde 0.249-1 \$ arasında iken, rejim kontrolü altındaki bölgelerde yaklaşık 0-0.13 \$ / m'tür (MoWR, Order: 894, 2014). Diğer taraftan, rejim kontrolü dişındaki bölgelere temin edilen su dezenfekte edilmediği için sağlıklı değildir. Daret Azza'dan ortaya çıkan sudan kaynaklanan hastalık göstergesi, Erken Uyarı ve Müdahale Ağı Programı raporlarına göre daha yüksektir (ACU, EWARN 2017).

8. Daret Azza topluluklarında kamu su şebekesinden sağlanan $1 \mathrm{~m}^{3}$ içme suyunun COS değeri 0.92-1.4 \$ arasındadır. Su yeraltı suyu tablasının derinliği, su ağlarının uzunluğu vb. birçok faktöre bağlı olarak sağlıklıdır.

9. Daret Azza halkı gelirlerinin \% 8-13'ünü güvensiz su satın almak için harcarken, rejime dayalı bölgelerde yaşayan insanlar ise gelirlerinin yaklaşık \% 0,5-1'ini su için harcamaktadır. 
$\mathrm{Bu}$ sonuçlardan da anlaşılacağı üzere, NSAG ve içme suyu sektörlerindeki insanlar kesintisiz mali ve teknik desteklere ihtiyaç duymaktadır. Bu nedenle, devlet dışı grupların kontrolündeki alanlarda yaşayan insanlar, özellikle içme suyuna erişimde acil, sürdürülebilir teknik ve mali olarak desteklenmelidir. 